\title{
3 From students' musicianship to their creative expressions
}

Od hudobnosti študentov $k$ ich kreatívnemu prejavu

DOI: 10.17846/HII.2017.20.221-246

Published by Constantine the Philosopher University in Nitra 2017, No. 20, pp. 221-246

ISSN: $1338-4872$

ニニニニニニニニニニニニニニニニニニニニニニニニニニニニニニニニニニニニニニニ

\section{Sabina Vidulin}

\section{Abstract:}

In the Croatian compulsory school teaching music is performed in all eight grades by one hour per week. The most common activities in regular class are singing, listening to music, playing instrument while the creative activity, mostly in the form of music making, is rarely carried out. The intention of the author is to describe in which way the students' musicianship (singing and playing) is implemented in Croatian schools and with which educational goals. As the author implies the close relationship of those activities with creativity, didactical methods for encouraging creativity after the realization of vocal and instrumental activities are going to be proposed in this paper. Besides regular music lessons, the attention is also given to the extracurricular music activities, in which the possibility of obtaining better creative students' results is even more.

$\checkmark$ chorvátskom systéme povinnej školskej výučby hudby sa hudobná výchova uči vo všetkých ôsmich ročníkov, a to jednu hodinu týždenne. Medzi najčastejšie činnosti počas bežnej hodiny hudby patrí spev, počúvanie hudby, hranie na nástroj, avšak tvorivé činnosti, väčšinou vo forme muzicírovania, sa vyskytne len zriedka. Zámerom autora je opísat', akým spôsobom je muzicírovanie študentov (spev a hranie) implementované $v$ chorvátskych školách, a s akými vzdelávacími ciel'mi sa výučbový proces uskutočňuje. Autor v článku naznačuje blízky vzt'ah týchto činností s kreativitou, didaktickými metódami, aby 
From students' musicianship to their creative expressions

sa podporila kreativita realizovania vokálnych a inštrumentálnych aktivit. Okrem pravidelnej hudobnej výchovy sa pozornost' venuje aj mimoškolskej hudobnej činnosti, $v$ ktorej je vyššia šanca získat' lepšie výsledky u tvorivých študentov.

\section{Keywords:}

didactical approach, extracurricular activities, musical creativity, music teaching, playing instrument, primary compulsory school, singing,

didaktický prístup, mimoškolské aktivity, hudobná tvorivost', hudobná výučba, hranie na nástroj, povinná školská dochádzka, spev.

Preface

Musical experience, expression of music and music making are an important part of a child's life. Singing, playing instrument, listening to music and creating music are important factors for the child's development and they are also dominant activities in kindergartens and schools. Reimer ${ }^{190}$ points out that music education should prospose different musical activities and the special role he gives to listen to music.

Musicianship is the most direct way of practicing music, which affects the students' musical expression and a way

190 REIMER, Bennett. 2003. A Philosophy of Music Education: Advancing the Vision (third edition). Upper Saddle River, New Jersey: Prentice Hall. ISBN 978-0130993380. 
Sabina Vidulin

of adoption of musical skills and knowledge related to music. By singing and playing instrument children experience, learn and understand music, and besides active musicianship they can express their creative inventions through music. School is a place where all these musical activities are carried out, but the results and the quality of music lessons depend on the teachers' expertise, the model and approach to music teaching and the students' work.

The Croatian compulsory school lasts eight years and for music lessons it has been allocated only one hour weekly, from the first to the eighth grade. ${ }^{191}$ According to the Nastavni plan i program za glazbenu kulturu ${ }^{192}$ [Teaching Plan and Programme for Music] and with the current teaching, so-called, open model, the goal of music in compulsory schools is focused on the development of students' musical culture, and it is based primarily on listening to and learning about musical pieces. With this mandatory field in working with students, the teacher can

${ }^{191}$ From the first to the third grade the music lessons are carried out by a general teacher, while from the fourth through eighth grade they are led by the specialist music teacher with a master's degree in the field of music pedagogy.

${ }^{192}$ Nastavni plan i program [Teaching Plan and Programme]. 2006. Zagreb: Ministarstvo znanosti, obrazovanja i sporta. pp. 66-78. 
choose additional activity as singing, playing instrument, creativity, musical literacy, dance.

The most common activity in regular music lessons is singing, but another form of musicianship found in school practice is the activity of playing an instrument. In the document Nastavni plan i program ${ }^{193}$ [Teaching Plan and Programme] it is pointed out that students should, among other things: "be encouraged for the independent musical activity (singing, playing)", so it is visible that attention is given to active musicianship, in practice and in the government document. Besides that, music textbooks are designed in a way to propose lots of songs for singing and playing.

An activity that is rarely carried out in regular classes is musical creativity (music making). Regarding this, our intention is focused on finding the possible didactical approach to present how the songs, which are primarily designed for singing or playing in regular class, may become templates for students' musical creativity.

${ }^{193}$ Nastavni plan i program [Teaching Plan and Programme]. 2006. Zagreb: Ministarstvo znanosti, obrazovanja i sporta. p. 67. 
3.1. Singing, playing instrument and creativity in regular music classes: general characteristics

Singing in the Croatian schools is based on learning songs by ear. Besides the goal to achieve the possible artistic level of singing, this activity has also didactical means, with the aim to help students in raising awareness of specific musical elements. In the song-learning process by ear, the following stages should be respected: body and the vocal exercises for singing; creation of the atmosphere and motivation for the song; song demonstration by the teacher. Learning a song by ear involves teachers' and students' common work: the teacher demonstrates one phrase and then the students repeat. After that the song is melodically-rhythmically correct and well-known, the music analysis of the song can be realized. The most important segment is the interpretation of the song, with all musical and aesthetic elements. The final goal is a nice and expressive singing, with clear vocal articulation, taking into consideration the tempo and dynamics of the song.

Playing instrument in regular class is not so often carried out, even if the benefits are multiple: from the development of students' musical competence to the 
From students' musicianship to their creative expressions

social interaction with others in the group. Mark ${ }^{194}$ points out that playing affects the development of cognitive skills and fine motor skills so the instrumental lessons should be proposed to students. By playing students learn selfdiscipline, they are diligent and engaged, learn to deal with success and defeat ${ }^{195}$. The research assignments from different studies ${ }^{196}$ indicate that children who had music lessons and instrument classes, increase their IQ. The fact is that children want to be active participants in the music activity and in that way they can perceive the essence of music more easily.

A larger number of songs that was intended for singing are also used for playing, especially those with simple melodic and rhythmic structure, and tonalities to two signs. The goal of playing in regular class ${ }^{197}$ is to master the basic

194 MARK, Michael L. 1987. Music Education's Cultural Imperative. Music Educators Journal, 74(4), 22-26. ISSN: 0027-4321.

195 COVAY, Elizabeth - CARBONARO, William. 2010. After the Bell: Participation in Extracurricular Activities, Classroom Behaviour, and Academic Achievement. Sociology of Education, 83(1), pp. 20-45. ISSN: 0038-0407.

196 SCHELLENBERG, E. Glenn. 2004. Music Lessons Enhance IQ. Psychological Science, 15(8), pp. 511-514. ISSN: 0956-7976.

197 In regular music class in Croatia, the mainly represented melodic instruments are block flutes (recorders), synthesizers and some traditional Croatian instruments. 
skills of playing melodic instruments ${ }^{198}$, make students active participants in the teaching process and to help them to better understand musical works.

Playing the instrument in regular class has several phases. The first phase is performing by playing different rhythmic structures. In the second phase musical notations are introduced and practiced by playing various didactical exercises. The third phase includes the independent song learning and it is based on the songs from the textbooks that students sing by ear, while the fourth phase is characterized by the independent students' work.

The practise and usefulness of singing and playing instrument may be visible especially in the possibilities of applying the acquired knowledge in order to create some new works.

The creative work of students in school is carried out from free improvisation realized through singing and playing to the leading one, in which children learn from their teacher what can be done with music works and in which manner.

\footnotetext{
198 Our intention is not to elaborate the playing of rhythmic instruments in class, but to highlight that the creative work of students is based on the fact that they can play a melodic instrument which helps them in music-making.
} 
It is important to encourage students' free expressions and discover their musical sensibility, but also to offer models which can be used in creating. The following activities may be taken as model for music making: text rhythmization, inventing melody to the text, changing melodic and rhythmic motifs and phrases from the known song, adding melody to the proposed rhythmical structure, inventing new text to an existing song, creating small musical forms (form of two or three-part: $A B, A B A, A B C$ ), adding the instrumental accompaniment to the song, adding another voice to the existing, etc.

Singing, playing and creativity are closely linked, and the teacher should find a way to use that connection in the best way. Since the practice in Croatian schools often shows that songs are used isolated, just for the purpose of singing or playing, it is our intention to propose some models to work in regular class, starting with singing or playing but followed with music-making. 


\section{2. Examples for encouraging creativity after singing and playing activity}

3. 2. 1. Singing and creativity (for students who do not know musical notation)

The song Jednu sem ružu mel199 is traditional, from the Croatian region Međimurje. It is written in $\mathrm{C}$ major, in triple meter, with the two-part structures in which the first four bars seem as one unit, and the second is represented by the next eight bars, where we may find the similarity in the melodical and rhythmical structures, but with the different ending. The song should be learned by ear with a great impact on the interpretation. After that, the creative work follows. It is important to feel the triple meter so students are going to hold the meter with one hand pulsing on the bench, in the tempo Moderato. While half of the class playing meter on the bench with left hand, highlighting the first note in every bar, the second half of the class improvises different rhythmic structures. After the joint work of the whole class, the students work in pairs and pay attention to the quality of the final work. The students

\footnotetext{
199 The song is taken from the music textbook for the fourth grade of compulsory school. MLADINIĆ, Igor. 2001. Glazba 4 [Music 4]. Zagreb: Školska knjiga. p. 63.
} 
From students' musicianship to their creative expressions

can use also the voice (neutral syllables) for the rhythmical improvisation.

\section{JEDNU SEM RUŽU MEL}

Hrvatska tradicijska skladba

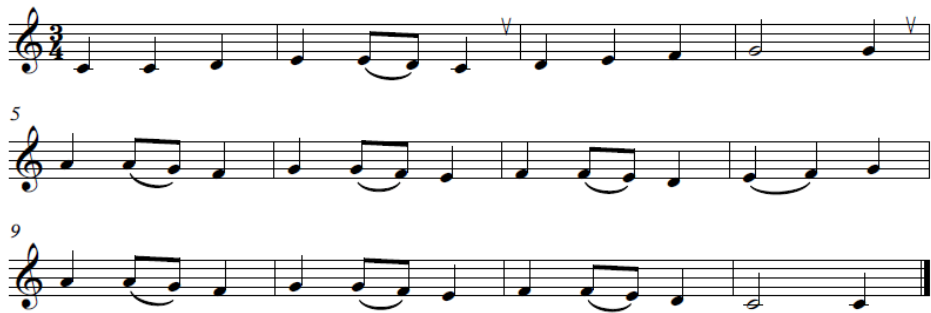

Annex 1. Song Jednu sem ružu mel

Playing and creativity (for students who are familiar with the music notation and play musical instruments at the elementary level).

After singing students learn to play the song by notes. The melody is moving gradually and is melodically and rhythmically simple. The second part has been repeated so it is easy to learn it. Then the creative students' work follows.

In Annex 2 the default meter and two bars can be seen. The teacher repeatedly reproduces these two bars by 
singing or playing, giving enough time to the students to start creating their own musical ideas and finish the example. Students can finish the example orally, playing at the instrument or directly writing.

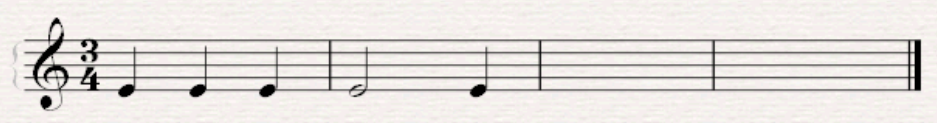

Annex 2. Rhythm continuation

\section{2. 2. Singing and creativity}

The song Lepe ti je Zagorje zelene 200 is traditional, from Zagorje. It is written in $\mathrm{G}$ major, in duple meter. It is characterized by quavers, fast movement, smaller leaps and repetition. The tempo is Allegro. The song is learned by ear. It is important to feel the whole made of eight bars, the repetition and melodic-rhythmical change which happens in the second bracket (seconda volta). After that, the task is to sing the song with neutral syllables, in an identical melo-rhythmic form, almost the entire song. In the second brackets (seconda volta), at the end of the song,

200 The song is taken from the music textbook for the fifth grade of compulsory school. JERKOVIĆ, Trpimir. 2001. Glazba 5 [Music 5]. Zagreb: Školska knjiga. p. 64. 
From students' musicianship to their creative expressions

the students should sing the same melody, but with a different rhythm. The teacher or group of students sing mostly the whole song, and one student sings the last four bars with rhythmical varieties.

\section{LEPETIJE ZAGORJE ZELENE}

Hrvatska tradicijska skladba
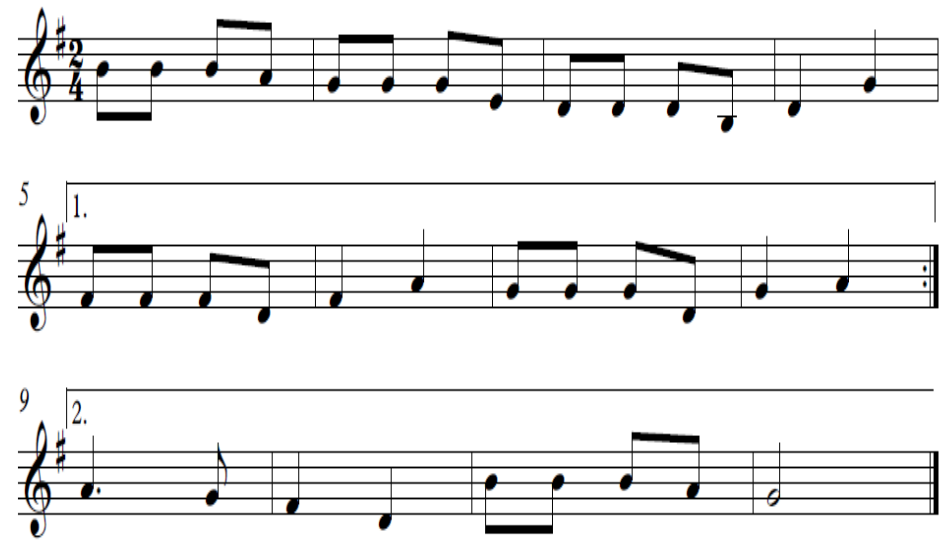

Annex 3. Song Lepe ti je Zagorje zelene

Playing and creativity

After singing and playing the song, the next task follows. In Annex 4 the rhythmic pattern in duple meter is defined, 
in total eight bars, which include quavers, quarters and half-notes, as in the song, and a pause. To the default rhythmic example the students add different tones and construct the melody. The tonality is not defined so the students have one open space for creating, with no tonality limit.

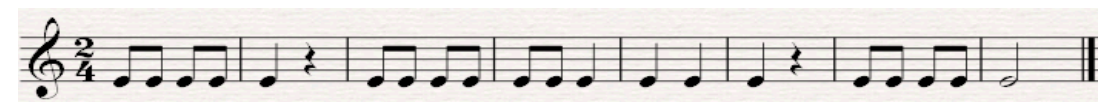

Annex 4. Making melody from the default rhythm

\section{2. 3 Singing and creativity}

The song Sretnuli smo puža 201 is traditional, from Međimurje. It is written in $\mathrm{F}$ major, duple meter. It has a pronounced rhythmic character and tones that are often repeated. The music unit requires constant movement. The form is closed, as one unit. It starts with an incomplete bar. The students learn the song by ear. The task is to continue the singing of the four bar melody with default text, after which one student develops the following four bars and immediately the third student adds other four 
From students' musicianship to their creative expressions

bars, completing the music unit of 12 bars. It is important that all three students are synchronized, that they sing one after the other and thereby gain a sense of teamwork in shaping music.

\section{SRETNULI SMO PUŽA}

Medimurje

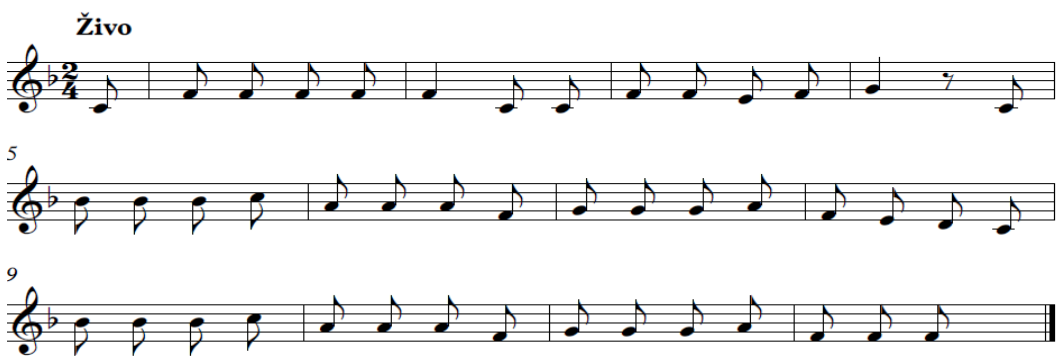

Annex 5. Song Sretnuli smo puža

Playing and creativity

After singing by ear, the students read the notes and play by notes. Then the music-making activity begins. In Annex 6 the $\mathrm{F}$ major tonality and triple meter are determined and the initial melodical-rhythmical pattern is given. A special feature is the incomplete bar. It is very important that the

201 The song is taken from the music textbook for the fifth grade of compulsory school. ŠPEHAR, Snježana. 2004. Glazba i ti 1 [Music 
Sabina Vidulin

teacher plays the melody several times. The students should pay attention to the tonality, measure and continue the proposed melody with some similarity in melodic or rhythmical way.

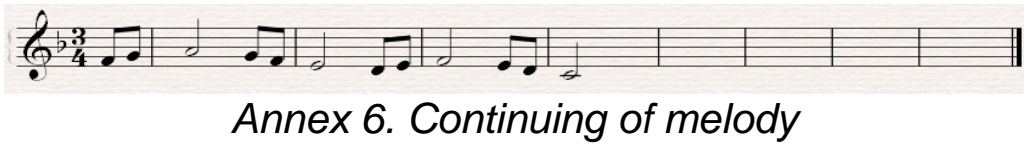

3. 3 Singing and creativity

The song Jedna stara majka ${ }^{202}$ is traditional, from Zagorje. Iti s written in e minor, in duple meter, in tempo Andante. The song is learned by ear. It is very important to get the song atmosphere, with a piano and mezzoforte dynamics. After the final interpretation, students can vary the entire melody rhythmically or melodically, converting the song from the minor in major tonality, changing the text. At the end of the process it is very important to talk about the

and you 1]. Zagreb: Školska knjiga. p. 64.

202 The song is taken from the music textbook for the fifth grade of compulsory school. ŠPEHAR, Snježana. 2004. Glazba i ti 1 [Music and you 1]. Zagreb: Školska knjiga. p. 52. 
From students' musicianship to their creative expressions

changes, the reasons, but also about the result that students achieve.

Jedna stara majka

Hrvatsko zagorje

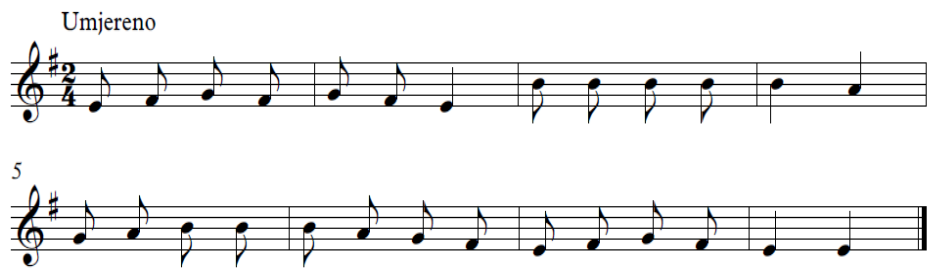

Annex 7. Song Jedna stara majka

Playing and creativity

The song is sung by ear to achieve the atmosphere. After that, the students analyze the structure of the song, the notation and play the song by notes. In Annex 7 a melodical-rhythmical example which students need to modify with new rhythmic and melodic patterns is defined. It is proposed to start and complete the melody in e minor to preserve the atmosphere. 


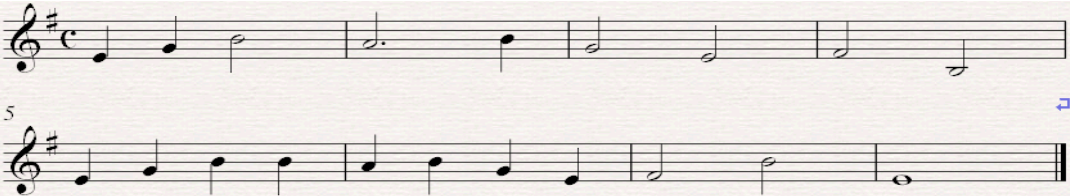

Annex 7. Changing the existing template and creating a new one

Encouraging students to explore and create music, which from the well-known songs create new rhythmic and melodic patterns or whole units, they develop their musical disposition and express themselves with and through music. When the teacher notices this students' capability, it is very important to find the possibility for upgrading it, and one of the possibility is to involve students in extracurricular musical activities in school.

\subsection{Extracurricular music activities in Croatian schools and creativity outcomes}

Extracurricular activities are a part of a wider free time context, which contributes to the children's development $^{203}$. The researches results show that

203 COOPER, Harris et. al. 1999. Relationships between five afterschool activities and academic achievement. Journal of Educational 
From students' musicianship to their creative expressions

extracurricular activities affect students' achievement, expand their school engagement and satisfaction with school $^{204}$. In addition to research, the teaching practice indicates successful works of students in extracurricular activities, which, in this way, expressed personal innovation, creative expression and acquire new competencies $^{205}$.

In addition to regular classes, extracurricular activities are an integral part of the primary compulsory school in Croatia. They have different characteristics so, besides cultural and artistic field they may have sports, technical, scientific, ecological character. Extracurricular activities are not regulated by the teaching plan and program. For a successful organization of the extracurricular activity teachers themselves have to create a stimulating program

Psychology, 91(2). 369-378. http://dx.doi.org/10.1037/00220663.91.2.369 ISSN 0022-0663.

${ }^{204}$ ECCLES, Jacquelynne S. et al. 2003. Extracurricular activities and adolescent development. Journal of Social Issues, 59(4), 865-889. DOI: 10.1046/j.0022-4537.2003.00095.x. ISSN: 1540-4560.

GILMAN, Rich - Meyers, Joel - Perez, Laura. 2004. Structured extracurricular activities among adolescents: Findings and implications for school psychologists. Psychology in the Schools, 41(1), 31-41. doi:10.1002/pits.10136 ISSN: 1520-6807.

205 PEJIĆ PAPAK, Petra - VIDULIN-ORBANIĆ, Sabina. 2011. Stimulating Active Learning in Extracurricular Activities through Contemporary Work Strategies. Metodički obzori, 12(2), 5-21. ISSN 1846-1484. 
with quality contents taking into consideration the age and students' abilities ${ }^{206}$.

In regard to the students' and teachers' preferences and the school equipment, the teacher develops an annual program for a particular activity. The music teacher arranges the program for one or more extracurricular activities, oriented vocally (solo singing, choir), instrumentally (playing an instrument, orchestra), or proposing folklore (singing, playing, dancing), creativity (music making, musicals, computer in music) etc. In Croatian schools students are interested to take part in the extracurricular musical activities, and the most common is the choir ${ }^{207}$. The goal of the extracurricular musical activities is to enable the development of musical skills of students, detect and improve their creative musical potential.

206 PEJIĆ PAPAK, Petra - VIDULIN, Sabina (2016). Izvannastavne aktivnosti u suvremenoj školi [Extracurricular activities in contemporary school]. Zagreb: Školska knjiga. ISBN 978-953-051709-7.

207 VIDULIN, Sabina. 2016. Extracurricular Musical Activities in Primary School from the Teachers' Point of View. In Music Education - Terra Cognita? Marek Sedláček (ed.). Brno: Masarykova univerzita. DOI: 10.5817/CZ.MUNI.P210-8443-2016. ISBN 978-80-210-8443-8, pp. 6-22. 
From students' musicianship to their creative expressions

The author of the paper realized many creative projects with students, as school musicals ${ }^{208}$, the $C^{209}$ with children's songs and is the coauthor with Emi Belušić and Maja Stanković of the SEM concept ${ }^{210}$ (stage-English language-music), but in this paper we will only briefly indicate what the possible outcomes of creativity in extracurricular music activities are.

Both examples ${ }^{211}$ were formed during the extracurricular musical activities (programs playing and music-making). The example entitled Metamorfoza (Annex 8) is an independent students' work. Improvising on the synthesizer he composed the song: first, he defined the

208 More in: VIDULIN-ORBANIĆ, Sabina. 2013. Glazbeno stvaralaštvo: teorijski i praktični prinos izvannastavnim glazbenim aktivnostima [Music creativity: theoretical and practical contribution to the extracurricular musical activities]. Pula: Udruga za promicanje kvalitete i poticanje izvrsnosti u odgoju i obrazivanju „SEM“ (e-book) ISBN 978-953-57557-0-8.

209 More in: VIDULIN-ORBANIĆ, Sabina. 2007. Izvannastavne (glazbene) aktivnosti: mjesto suživota, kreativnosti i stvaralaštva [Extracurricular musical activities: place of coexistation and creativity]. Rovinj: OŠ Vladimira Nazora. ISBN 978-953-55013-0-5.

210 More in: VIDULIN, Sabina. 2014. The challenge of interdisciplinary approach in music education. Petr Hala (ed.) Musica viva in schola XXIV. Brno: Masarykova univerzita, pp. 30-41. DOI:

10.5817/CZ.MUNI.P210-7565-2014 ISBN 978-80-210-7565-8.

211 More in: VIDULIN, Sabina. 2016. Glazbeno stvaralaštvo u primarnom obrazovanju: perspektiva i retrospektiva. [Musical creativity in primary education: retrospective and perspective]. Vito Balić and Davorka Radica (eds.) Glazbena pedagogija u svjetlu sadašnjih i 
Sabina Vidulin

tonality, meter and the number of bars, and started playing different melodies. When he invented a phrase that he liked, he wrote it and continued with finding a new one. Having devised a whole, he determined the dynamics and tempo. The teacher helped in the harmonization.

\section{Moderato $(\bullet=71)$}
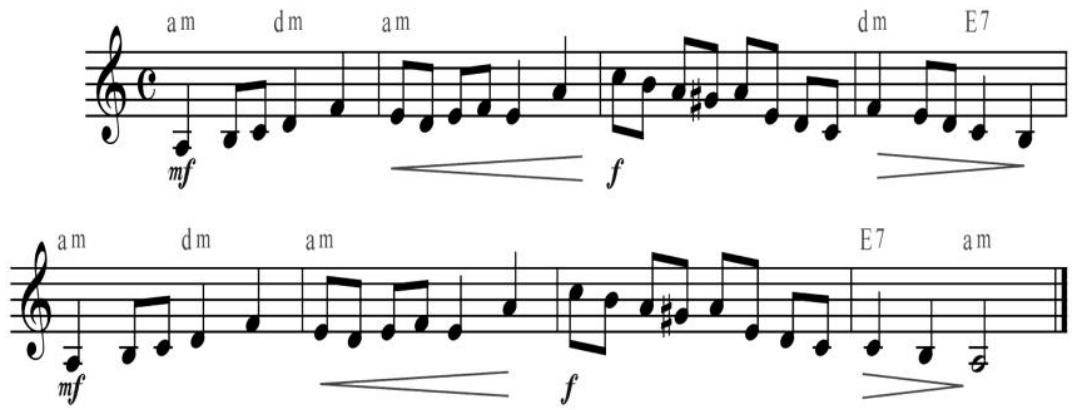

Annex 8. Metamorfoza ${ }^{212}$, individual students' work

The song Ljeto (Annex 9) was created as a joint students' work. The work has started by creating the text on the topic, after which the group along with the mentor established the tonality and meter. When the text was rhythmically defined, the children played different melodies

budućih promjena 4. Split: Sveučilište u Splitu, Umjetnička akademija, pp. 15-32. ISBN 978-953-6617-37-1.

212 Metamorfoza (Metamorphosis) was recorded on the album Tvoja staza (Your Path) which is an integral part of the multimedia- 
From students' musicianship to their creative expressions

on that pattern. The teacher wrote on the blackboard the one students liked the most. After the melo-rhythmical completion of the song, tempo, dynamics, and harmonic accompaniment were defined.

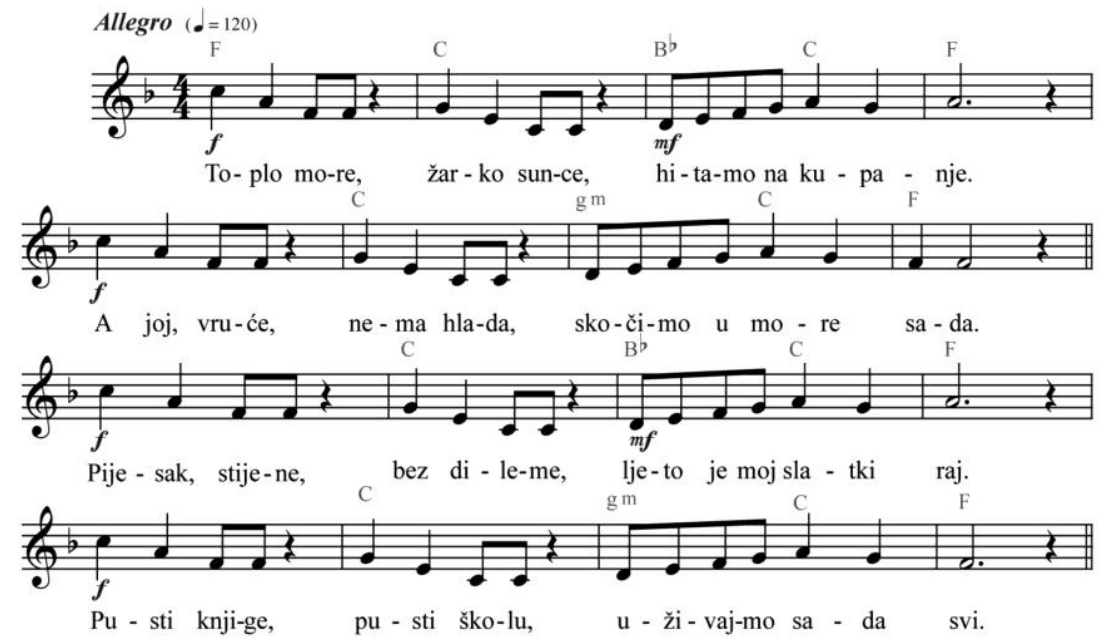

Annex 9. Ljeto ${ }^{213}$, collective work of students

While working with students in extracurricular music activities musical gifted students can be recognized, those who have shown the greatest interest in music and those who have expressed a distinct musicality. Through the

monograph (VIDULIN-ORBANIĆ, Sabina. 2007. ibid. p. 76). The piece of music was signed by Florijan Karh.

213 The song Ljeto (Summer) was recorded by the school choir Vladimir Nazor Rovinj and is also part of the album Tvoja staza (Your Path). More in: VIDULIN-ORBANIĆ, Sabina. 2007. (ibid., p. 87). 
work of the shown annexes, therefore, during the creative process, the students revealed something different, transformed the existing, researched and created a new, unique creation. In that way they acquired knowledge, developed their musical skills, expressed their thoughts critically and creatively. These and similar models guarantee a music lesson closed to a child, which encourages its individual development. Therefore, music classes and extracurricular musical activities should be taken very seriously into consideration because they are great partners on the long road of contemporary education and directly affect the acquisition of competencies for life and work.

\section{REFERENCES:}

COVAY, Elizabeth - CARBONARO, William. 2010. After the Bell: Participation in Extracurricular Activities, Classroom Behaviour, and Academic Achievement. In Sociology of Education, vol. 83, no. 1. ISSN 0038-0407, 2010, pp. 20-45.

COOPER, Harris - VALENTINE, Jeffrey C. - NYE, Barbara - LINDSAY, James J. 1999. Relationships between five after-school activities and academic achievement. In Journal of Educational Psychology, vol. 91, no. 2. ISSN 0022-0663, 1999, $\mathrm{pp}$. 369-378. http://dx.doi.org/10.1037/0022-0663.91.2.369 
ECCLES, Jacquelynne S. - BARBER, Bonnie L. - STONE, Margaret - HUNT, James. 2003. Extracurricular activities and adolescent development. In Journal of Social Issues, vol. 59, no. 4. ISSN: 1540-4560, 2003, pp. 865-889. DOI: 10.1046/j.0022-4537.2003.00095.x

GILMAN, Rich - MEYERS, Joel - PEREZ, Laura. 2004. Structured extracurricular activities among adolescents: Findings and implications for school psychologists. In Psychology in the Schools, vol. 41, no. 1 ISSN: 15206807, 2004, pp. 31-41. doi:10.1002/pits.10136.

MARK, Michael L. 1987. Music Education's Cultural Imperative. In Music Educators Journal, vol. 74, no. 4. ISSN 0027-4321, 1987, pp. 22-26.

MLADINIĆ, Igor. 2001. Glazba 4 [Music 4]. Zagreb: Školska knjiga.

JERKOVIĆ, Trpimir. 2001. Glazba 5 [Music 5]. Zagreb: Školska knjiga.

NASTAVNI PLAN I PROGRAM [Teaching Plan and Programme]. 2006. Zagreb: Ministarstvo znanosti, obrazovanja i sporta, 2006, pp. 66-78.

PEJIĆ PAPAK, Petra - VIDULIN-ORBANIĆ, Sabina. 2011. Stimulating Active Learning in Extracurricular Activities through Contemporary Work Strategies. In Metodički obzori, vol. 12, no. 2. ISSN 1846-1484, 2011, pp. 5-21.

PEJIĆ PAPAK, Petra - VIDULIN, Sabina. 2016. Izvannastavne aktivnosti u suvremenoj školi 
[Extracurricular activities in contemporary school]. Zagreb: Školska knjiga. ISBN 978-953-0-51709-7.

REIMER, Bennett. 2003. A Philosophy of Music Education: Advancing the Vision (third edition). Upper Saddle River, New Jersey: Prentice Hall. ISBN 9780130993380.

SCHELLENBERG, E. Glenn. 2004. Music Lessons Enhance IQ. In Psychological Science, vol. 15, no. 8. ISSN: 0956-7976, 2004, pp. 511-514.

ŠPEHAR, Snježana. 2004. Glazba i ti 1 [Music and you 1]. Zagreb: Školska knjiga.

VIDULIN-ORBANIĆ, Sabina. 2007. Izvannastavne (glazbene) aktivnosti: mjesto suživota, kreativnosti i stvaralaštva [Extracurricular musical activities: place of coexistation and creativity]. Rovinj: OŠ Vladimira Nazora. ISBN 978-953-55013-0-5.

VIDULIN-ORBANIĆ, Sabina. 2013. Glazbeno stvaralaštvo: teorijski i praktični prinos izvannastavnim glazbenim aktivnostima [Music creativity: theoretical and practical contribution to the extracurricular musical activities]. Pula: Udruga za promicanje kvalitete i poticanje izvrsnosti u odgoju i obrazivanju „SEM“ (e-book). ISBN 978-953-57557-0-8.

VIDULIN, Sabina. 2014. The challenge of interdisciplinary approach in music education. Petr Hala (ed.) Musica viva in schola XXIV. Brno: Masarykova univerzita. ISBN 97880-210-7565-8, 2014, pp. 30-41. DOI:

10.5817/CZ.MUNI.P210-7565-2014. 
VIDULIN, Sabina. 2016. Extracurricular Musical Activities in Primary School from the Teachers' Point of View. In Music Education - Terra Cognita? Marek Sedláček (ed.). Brno: Masarykova univerzita. ISBN 978-80-210-8443-8, 2016, pp. 6-22. DOI: 10.5817/CZ.MUNI.P210-8443-2016.

VIDULIN, Sabina. 2016. Glazbeno stvaralaštvo u primarnom obrazovanju: perspektiva i retrospektiva. [Musical creativity in primary education: retrospective and perspective]. Vito Balić i Davorka Radica (eds.) Glazbena pedagogija u svjetlu sadašnjih i budućih promjena 4. Split: Sveučilište u Splitu, Umjetnička akademija, ISBN 978-9536617-37-1, 2016, pp. 15-32.

\section{Contact information:}

Sabina Vidulin, Ph.D. assistant professor

Music Academy in Pula,

University of Juraj Dobrila in Pula

Zagrebačka 30, Pula, Croatia

E-mail: svidulin@unipu.hr 